\title{
PARAMETER FISIKA, KIMIA DAN BAKTERIOLOGI AIR MINUM ALKALI TERIONISASI YANG DIPRODUKSI MESIN KANGEN WATER LeveLuk SD 501
}

\author{
Ita Emilia $^{1^{*}}$, Dian Mutiara ${ }^{2}$ \\ e-mail : itaemilia742@gmail.com \\ ${ }^{1,2)}$ Program Studi Biologi Fakultas Matematika dan Ilmu Pengetahuan Alam \\ Universitas PGRI Palembang
}

\begin{abstract}
Ionized alkaline drinking water is alkaline and has a high redox potential value which is a good antioxidant. Considering the consumption of alkaline drinking water there are still pros and cons in society because research on ionized alkaline water in Indonesia has not been widely published yet, so the researchers intend to conduct research on the physical, chemical and bacteriological parameters of ionized alkaline drinking water produced by Kangen Water LeveLuk machines SD 501 with the aim of knowing the quality of ionized alkaline drinking water, based on physical, chemical and bacteriological parameters. This research is descriptive qualitative. The quality inspection of ionized alkaline drinking water is carried out at the South Sumatra Provincial Health Office Laboratory, which includes examining physical parameters (odor, turbidity, taste, color, amount of dissolved solids (TDS)), chemical parameters (including $\mathrm{pH}$, iron, fluoride, hardness checks , chloride, chromium valence 6, manganese, nitrate, nitrite, zinc, cyanide, sulfate, copper, aluminum), and bacteriological testing (including tests for coliform and colitinja). Based on the results of the study, the samples of ionized alkaline drinking water produced by households located in Lorong Amilin Rt 4 Rw 2, Kelurahan Tangga Takat, Seberang Ulu II, Plaju Palembang fulfilled the requirements stipulated under the Minister of Health Regulation of the Republic of Indonesia No.492 / MENKES / PER / IV / 2010.
\end{abstract}

Keywords: ionized alkaline water, physical, chemical, bacteriological parameters

\begin{abstract}
ABSTRAK
Air minum alkali terionisasi adalah air minum yang bersifat basa ( $\mathrm{pH}$ umunya berkisar antara 8,5-9,5) memiliki nilai potensial redoks dan kandungan antioksidan yang tinggi. Mengingat konsumsi air minum yang bersifat alkali masih terdapat pro dan kontra dimasyarakat karena penelitian tentang air alkali terionisasi di Indonesia juga belum banyak dipublikasikan, maka peneliti bermaksud melakukan penelitian tentang parameter fisika, kimia dan bakteriologi dari air minum beralkali terionisasi yang diproduksi mesin Kangen Water LeveLuk SD 501. Penelitian ini bersifat deskriptif kualitatif. Pemeriksaan kualitas air dilaksanakan di Laboratorium Dinas Kesehatan Provinsi Sumatera Selatan, yaitu meliputi pemeriksaan parameter fisika (bau, kekeruhan, rasa, warna, jumlah zat padat terlarut (TDS)), parameter kimia (mencakup pemeriksaan $\mathrm{pH}$, besi, fluoride, kesadahan, klorida, kromium valensi 6 , mangan, nitrat, nitrit, seng, sianida, sulfat, tembaga, alumunium), dan pengujian bakteriologi (meliputi uji adanya coliform dan colitinja). Berdasarkan hasil penelitian menunjukkan bahwa sampel air minum alkali terionisasi yang diproduksi indistri rumah tangga yang berlokasi di Kelurahan Tangga Takat Kecamataan Seberang Ulu II Plaju Palembang memenuhi persyaratan yang ditetapkan berdasarkan Peraturan Menteri Kesehatan Republik Indonesia No.492/MENKES/PER/IV/2010.
\end{abstract}

Kata Kunci : air alkali terionisasi, parameter fisik, kimia, bakteriologi 


\section{PENDAHULUAN}

Menurut Peraturan Menteri Kesehatan Republik Indonesia nomor 492 tahun 2010, air minum adalah air yang melalui proses pengolahan atau tanpa proses pengolahan yang memenuhi syarat kesehatan dan dapat langsung diminum. Air minum aman bagi kesehatan apabila memenuhi persyaratan fisika, kimia, bakteriologis, dan radioaktif (Permenkes RI, 2010 dalam Amani dan Kiki, 2016).

Pemilihan parameter-parameter penting dalam pengukuran air ini agar dapat memenuhi ketentuan air yang baik yaitu tidak berasa, berbau dan berwarna. Parameter kimia antara lain adalah $\mathrm{pH}$ air yang merupakan parameter kimia organik. Parameter fisika antara lain suhu dan TDS. Suhu air yang melebihi batas normal menunjukkan indikasi terdapat bahan kimia yang terlarut dalam jumlah yang cukup besar atau sedang terjadi proses dekomposisi bahan organik oleh mikroorganisme (Astari dan Rofiq, 2009). Tingginya level TDS memperlihatkan hubungan negatif dengan beberapa parameter lingkungan air yang menyebabkan meningkatnya toksisitas pada organism didalamnya. Parameter biologi umumnya digunakan untuk melihat adanya koloni Eschericia coli dan mikroba yang lain (Timpano et al., 2010).

Air alkali adalah air yang bersifat basa dan mempunyai $\mathrm{pH}$ umumnya berkisar antara $\mathrm{pH} 7-9,5$. Air alkali terionisasi (AAT) merupakan air yang memiliki nilai potensial redoks yang tinggi (yakni merupakan antioksidan yang baik karena nilai ORP (Oxydation Reduction Potensial) yang sangat negatif) dan memiliki molekul air dalam kelompok yang lebih kecil daripada air biasa (microclustred) (Rosa et al., 2012). Terdapat aplikasi dari minuman elektrolit pada kehidupan sehari-hari, air elektrolit asam dan basa. Air asam tidak cocok sebagai konsumsi manusia, namun cukup bermanfaat untuk perawatan dan kebersihan tubuh. Di lain sisi, air basa sangat memungkinkan untuk diminum dan direkomendasikan untuk mengatasi masalah gastro-intestinal, hipertensi, diabetes, kanker (Henry dan Chambron, 2013).

Buck (2002) mengemukakan $\mathrm{pH}$ adalah kuantitas dari ion tunggal berupa aktivitas dari ion hidrogen, yang tak terukur dengan metode termodinamika yang valid dan memerlukan konversi untuk analisisnya. Dalam mengekspresikan keasaman dan kebasaan memiliki rentang 0 hingga 14. Larutan asam memiliki $\mathrm{pH}$ dibawah 7,0 dan larutan basa memiliki $\mathrm{pH}$ diatas 7,0 .

Air alkali bersifat mikro yang memiliki kemampuan penyerapan oleh tubuh yang tak tertandingi. Kaya akan mineral alkali, membantu dalam buffering kondisi asam dalam tubuh. Dengan kelimpahan elektron yang tersedia, AAT membuat sel menghancurkan radikal bebas berbahaya (Khushboo et al., 2014).

Manfaat air alkali dalam kesehatan menurut Ignacio et al. (2013) adalah air alkali telah diakui oleh Pemerintah Korea dan Jepang sebagai minuman yang berkhasiat untuk memperbaiki fermentasi usus yang abnormal, diare kronis, hyperacidity pada lambung dan dyspepsia.

Air alkali terionisasi juga bermanfaat dalam pencegahan termutakhir timbulnya kanker (Catur dan Asep, 2016). Kanker merupakan penyakit yang disebabkan oleh pertumbuhan sel secara abnormal, yaitu sel nya bertumbuh dengan cepat dan tidak terkontrol, dimana sel tersebut menginfiltrasi dan menekan sel tersebut sehingga ia dapat mempengaruhi organ tubuh di sekitarnya ataupun yang tidak berada di sekitarnya. (Wan- Jun et al., 2013). Shirahata et al. (2012) meneliti bahwa air alkali terionisasi merupakan air yang bersifat basa, kaya akan komponen hidrogen, sedikit molekul air dan memiliki potensial redoks negatif. Air ini diketahui 
memiliki aktivitas antioksidan karena dapat mengurangi radikal bebas atau reactive oxygen species (ROS) dalam tubuh.

Ciri paraklinis umum pada sel tumor maupun kanker adalah produksi asam laktat dan asam piruvat yang tinggi, oksidasi glukosa yang rendah. (Thomas et al., 2008). Air alkali terionisasi dapat menghilangkan oksigen aktif dan melindungi DNA dari kerusakan oksidatif yang disebabkan oleh kanker (Deanna and James, 2006).

\section{BAHAN DAN METODE}

\section{Metode Penelitian}

Penelitian ini bersifat deskriptif kualitatif yang menggambarkan hasil evaluasi kualitas air minum alkali terionisasi yang diproduksi oleh mesin Kangen Water Tipe LeveLuk SD 501. Sampel yang dianalisa diambil dari air minum beralkali yang diproduksi oleh industri rumah tangga yang beralamat di Lorong Amilin Rt 4 Rw 2 Kelurahan Tangga Takat Kecamatan Seberang Ulu II Plaju Palembang. Pemeriksaan kualitas air minum alkali terionisasi dilaksanakan di Laboratorium Dinas Kesehatan Provinsi Sumatera Selatan, yaitu meliputi pemeriksaan parameter fisika, parameter kimia, dan pengujian bakteriologi.

\section{Alat dan Bahan}

Alat yang digunakan yaitu botol sampel, neraca analitik, spektrofotometer, turbidimeter, $\mathrm{pH}$ meter, inkubator, autoclave, buret dan statif, cawan goch, tabung reaksi, tabung durham, pipet volume, bunsen, gelas ukur, gelas kimia, oven, desikator, ose.

Bahan yang dipakai antara lain lactose broth (LB), brilliant green lactose bile broth (BGLB), endo agar (EMB), aquadest, kertas saring, asam klorida, hidroksilamin klorida, dapar ammonium asetat, phenantrolin, buffer $\mathrm{pH}$ 10, EDTA dan EBT, $\mathrm{AgNO}_{3}, \quad \mathrm{~K}_{2} \mathrm{CrO}_{4}, \mathrm{KMnO}_{4}$, $\mathrm{H}_{2} \mathrm{SO}_{4}$.

\section{Pemeriksaan Laboratorium}

Pemeriksaan uji laboratorium yang dilaksanakan mewakili parameter fisik, kimia dan mikrobiologi yang ada dalam Permenkes 492 tahun 2010, meliputi :

a. Parameter fisika meliputi pemeriksaan bau, kekeruhan, rasa, warna, jumlah zat padat terlarut (TDS).

b. Parameter kimia mencakup pemeriksaan $\mathrm{pH}$, besi, fluoride, kesadahan, klorida, kromium valensi 6, mangan, nitrat, nitrit, seng, sianida, sulfat, tembaga, alumunium.

c. Pengujian bakteriologi meliputi uji adanya coliform dan colitinja.

\section{HASIL DAN PEMBAHASAN}

Berdasarkan hasil pemeriksaan terhadap sampel air minum bersifat alkali terionisasi, diperoleh data yang ditunjukkan pada tabel 1 yang menunjukkan hasil bahwa sampel air minum alkali terionisasi yang dihasilkan mesin Kangen Water Tipe LeveLuk SD 501 yang diproduksi di daerah Lorong Amilin Rt 4 Rw 2 Kelurahan Tangga Takat Kecamatan Seberang Ulu Plaju Palembang telah memenuhi persyaratan semua parameter kualitas air minum, yang meliputi parameter fisika, kimia, dan bakteriologi berdasarkan Baku Mutu Air Minum Sesuai Permenkes No. 492/Menkes/Per/IV/2010.

Syarat kimia dalam hal ini yaitu tidak adanya kandungan unsur atau zat kimia yang berbahaya bagi manusia. Keberadaan zat kimia berbahaya harus ditekan seminimal mungkin. Sedangkan zat-zat tertentu yang membantu terciptanya kondisi air yang aman dari mikroorganisme harus tetap dipertahankan keberadaannya dalam kadar tertentu. Parameter dalam persyaratan ini terbagi 
menjadi dua yaitu bahan kimia yang berpengaruh langsung pada kesehatan dan menimbulkan keluhan pada konsumen. Bahan kimia yang termasuk didalam parameter ini adalah bahan anorganik, organik, dan $\mathrm{pH}$. Parameter persyaratan bakteriologis adalah jumlah maksimum E.coli dan total bakteri Coliform per 100 $\mathrm{ml}$ sampel (Permenkes No. 492/Menkes/Per/IV/2010). pH merupakan singkatan dari pouvoir hydrogene dan menunjukkan konsentrasi ion hidrogen dalam air. $\mathrm{pH}$ digunakan untuk mengetahui tingkat kebasaan dan keasaman air. $\mathrm{pH}$ mempengaruhi toksisitas suatu senyawa kimia. Senyawa amonium yang dapat terionisasi banyak ditemukan pada perairan yang memiliki $\mathrm{pH}$ rendah. (Budiyono dan Sumardiono, 2013). Inti dari pengolahan air minum adalah menurunnya atau hilangnya semua polutan zat pencemar baik pencemar fisik, kimia, mikrobiologis dan radioaktif di dalam air sehingga air tersebut aman dan layak dikonsumsi (Yudo dan Rahardjo, 2005).

Parameter fisika yang diperiksa meliputi bau, kekeruhan, rasa, warna, dan jumlah zat padat terlarut (TDS). Air minum yang berbau, selain tidak estetis juga tidak disukai oleh masyarakat. Bau air dapat memberi petunjuk terhadap kualitas air, misalnya bau amis dapat disebabkan oleh adanya algae dalam air tersebut. Kekeruhan menggambarkan sifat optik air yang ditentukan berdasarkan banyaknya cahaya yang diserap dan dipancarkan oleh bahan-bahan yang terdapat di dalam air. Kekeruhan disebabkan adanya bahan organik dan anorganik yang tersuspensi dan terlarut. Air minum biasanya tidak memberikan rasa (tawar). Air yang berasa menunjukkan kehadiran berbagai zat yang dapat membahayakan kesehatan. Berdasarkan Keputusan Menteri Kesehatan RI Nomor 492/Menkes/Per/VI/2010, diketahui bahwa syarat air minum yang dapat dikonsumsi manusia adalah tidak berasa. Air minum sebaiknya tidak berwarna untuk alasan estetika dan untuk mencegah keracunan dari berbagai zat kimia maupun mikroorganisme yang berwarna. Warna pada air disebabkan oleh adanya partikel hasil pembusukan bahan organik. Analisa zat padat dalam air digunakan untuk menentukan komponenkomponen air secara lengkap, proses perencanaan, serta pengawasan terhadap proses pengolahan air minum. Padatan terlarut total (Total Dissolved Solid atau TDS) merupakan bahan-bahan terlarut (diameter $<10^{-6} \mathrm{~mm}$ ) dan koloid (diameter $10^{-6} \mathrm{~mm}-10^{-3} \mathrm{~mm}$ ) yang berupa senyawa-senyawa kimia dan bahan-bahan lain, yang tidak tersaring pada kertas saring berdiameter $0,45 \mu \mathrm{m}$. TDS tidak diinginkan dalam air minum karena dapat menimbulkan warna, rasa, dan bau yang tidak sedap. Beberapa senyawa kimia pembentuk TDS bersifat racun dan merupakan senyawa organik bersifat karsinogenik (Effendi, 2003). Air Alkali Terionisasi dapat mencegah terjadinya keadaan asam dalam tubuh kita dan menjadikan tubuh kita menjadi lingkungan yang basa (Catur dan Asep, 2016).

Mengkonsumsi air alkali yang diionisasi dapat meningkatkan alkalinitas dalam tubuh, selain itu penggunaan negatif ORP (Oxidation Reduction Potential) dapat menetralisir radikal bebas. Air alkali bermuatan listrik negatif dan tereduksi, yaitu bersifat low micro clustering (memiliki ukuran partikel yang kecil) dari molekul air biasa sehingga mengurangi tegangan permukaan air tersebut dan memiliki daya larut dan daya serap sel yang lebuh besar. Air alkali yang disarankan boleh diminum berkisar antara $\mathrm{pH} 7.0$ - $\mathrm{pH}$ 9.5. Konsumsi air alkali dengan $\mathrm{PH}$ 9,5 maupun kombinasi antara air alkali $\mathrm{pH} 9,5$ dan strong water alkali $\mathrm{pH}$ 11,5 terbukti efektif untuk menurunkan GDA (gula darah acak) pada penderita diabetes mellitus tipe 2 (Siswantoro et al., 2018). 
Tabel 1. Hasil pemeriksaan parameter fisika, kimia, dan bakteriologi sampel air minum beralkali terionisasi

\begin{tabular}{|c|c|c|c|c|c|}
\hline No & Parameter & Satuan & $\begin{array}{c}\text { Kadar } \\
\text { Maksimum } \\
\text { yang } \\
\text { Diperbolehkan }\end{array}$ & $\begin{array}{c}\text { Hasil } \\
\text { Pemeriksaan }\end{array}$ & Ket \\
\hline & A. FISIKA & & & & \\
\hline 1. & $\mathrm{Bau}$ & - & Tidak Berbau & Tidak Berbau & MS \\
\hline 2. & Kekeruhan & Skala NTU & 5 & 0,68 & MS \\
\hline 3. & Rasa & - & Tidak Berasa & Tidak Berasa & MS \\
\hline 4. & Warna & Skala CTU & 15 & 0,8 & MS \\
\hline 5. & $\begin{array}{l}\text { Jumlah Zat Padat } \\
\text { Terlarut (TDS) }\end{array}$ & $\mathrm{Mg} / \mathrm{L}$ & 500 & 7,45 & MS \\
\hline & B. KIMIA & & & & \\
\hline 1. & Besi & $\mathrm{Mg} / \mathrm{L}$ & 0,3 & 0,03 & MS \\
\hline 2. & Fluorida & $\mathrm{Mg} / \mathrm{L}$ & 1,5 & 0,01 & MS \\
\hline 3. & Kesadahan $\left(\mathrm{CaCO}_{3}\right)$ & $\mathrm{Mg} / \mathrm{L}$ & 500 & 7 & MS \\
\hline 4. & Klorida & $\mathrm{Mg} / \mathrm{L}$ & 250 & 0,3 & MS \\
\hline 5. & Kromium valensi 6 & $\mathrm{Mg} / \mathrm{L}$ & 0,05 & 0,02 & MS \\
\hline 6. & Mangan & $\mathrm{Mg} / \mathrm{L}$ & 0,4 & 0,018 & MS \\
\hline 7. & N. sebagai Nitrat & $\mathrm{Mg} / \mathrm{L}$ & 50 & 0,9 & MS \\
\hline 8. & N. sebagai Nitrit & $\mathrm{Mg} / \mathrm{L}$ & 3,0 & 0,004 & MS \\
\hline 9. & $\mathrm{pH}$ & - & $6,5-8,5$ & 7,3 & MS \\
\hline 10. & Seng & $\mathrm{Mg} / \mathrm{L}$ & 3,0 & 0,05 & MS \\
\hline 11. & Sianida & $\mathrm{Mg} / \mathrm{L}$ & 0,07 & 0,001 & MS \\
\hline 12. & Sulfat & $\mathrm{Mg} / \mathrm{L}$ & 250 & 5 & MS \\
\hline 13. & Tembaga & $\mathrm{Mg} / \mathrm{L}$ & 2,0 & 0,05 & MS \\
\hline 14. & $\begin{array}{l}\text { Aluminium } \\
\text { C. BAKTERIOLOGI }\end{array}$ & $\mathrm{Mg} / \mathrm{L}$ & 0,2 & 0,082 & MS \\
\hline 1. & Coliform & $\mathrm{MPN} / 100 \mathrm{ml}$ & 0 & 0 & MS \\
\hline 2. & Colitinja & $\mathrm{MPN} / 100 \mathrm{ml}$ & 0 & 0 & MS \\
\hline
\end{tabular}

Keterangan :

MS : Memenuhi Syarat berdasarkan Baku Mutu Air Minum Sesuai Permenkes No. 492/Menkes/Per/IV/2010.

Pada beberapa penelitian air alkali menunjukkan efek positif terhadap perbaikan beberapa keadaan penyakit melalui modulasi sel-sel imun tubuh. Pada kasus distress pernapasan sebagai contoh asma, adanya kadar $\mathrm{PaCO}_{2}$ yang cenderung tinggi dalam darah dapat menyebabkan penurunan $\mathrm{pH}$ darah yang biasa disebut asidosis respiratorik. Adanya darah yang cenderung asam dan lingkungan saluran napas yang cenderung asam pula, diketahui sel-sel inflamasi yang sudah sudah hiperreaktif dalam darah dan saluran napas akan mengalami hambatan dalam apoptosis sel. Sel-sel inflamasi dimana proses apoptosis sel terhambat akan menyebabkan peningkatan konsentrasi sel-sel inflamasi yang menjadi faktor penyebab mengapa semakin berat derajat asma, semakin tinggi pula frekuensi munculnya serangan asma (Kilmet, 2013 dalam Yustina et al., 2016). 


\section{KESIMPULAN}

Pengujian kualitas sampel air minum beralkali terionisasi yang diproduksi mesin Kangen Water Tipe LeveLuk SD 501 berdasarkan parameter fisik (bau, kekeruhan, rasa, warna, jumlah zat padat terlarut (TDS)), parameter kimia (mencakup pemeriksaan $\mathrm{pH}$, besi, fluoride, kesadahan, klorida, kromium valensi 6, mangan, nitrat, nitrit, seng, sianida, sulfat, tembaga, alumunium), dan pengujian bakteriologi (meliputi uji adanya coliform dan colitinja telah memenuhi persyaratan yang ditetapkan berdasarkan Peraturan Menteri Kesehatan Republik Indonesia No.492/Menkes/Per/IV/2010.

\section{DAFTAR PUSTAKA}

Amani , Fauzi., Kiki, Prawiroredjo. (2016). Alat Ukur Kualitas Air Minum dengan Parameter $\mathrm{pH}$, Suhu, Tingkat Kekeruhan, dan Jumlah Padatan Terlarut. JETri, 14(1), 4962.

Astari, Rahmita ., Rofiq, Iqbal. (2009). Kualitas Air Dan Kinerja Unit Pengolahandi Instalasi Pengolahan Air Minum. ITB.

Buck, R. P. (2002). Measurement of pH.

Definition, Standards, And Procedures (IUPAC

Recommendations 2002). Pure and applied chemistry 74(11), 21692200.

Catur, M Marliando Satria Pangestu., Asep, Sukohar. (2016). Air Alkali Terionisasi Pencegahan

Termutakhir Timbulnya Kanker. Majority, 5(2), 74-80.
Deanna C and James, KB. (2006). Gene Therapy For Cancer Treatment: Past, Present And Future. Clin Med Res. 4(3), 218-27.

Effendi, Hefni, (2003). Telaah Kualitas Air Bagi Pengelolaan Sumber Daya dan

Perairan. Yogyakarta Lingkungan

Kanisius.

Henry, M. dan Chambron, J. (2013). Physico-Chemical, Biological and Therapeutic Characteristics of Electrolyzed Reduced Alkaline Water (ERAW). Water, 5(4), 20942115.

\section{https://infokangenwater.id/2017/06/apa- itu-air-alkali.html}

\section{https://www.kangenairkesehatan.com/k angen-water-menurut-dokter- dan-ahli-nutrisi-diterjemahkan- ke-dalam-bahasa-indonesia/}

Ignacio RMC, Kwak H, Yun Y, Easter M, Sajo J V, Yoon Y. (2013). The Drinking Effect of Hydrogen Water on Atopic Dermatitis Induced by Dermatophagoides farinae Allergen in NC / Nga Mice. Evidence-based Complement Altern Med :1-5.

Kementerian Kesehatan, Peraturan Menteri Kesehatan No. 492/Menkes/Per/IV/ 2010. [sitasi 29 November 2011], tersedia di http:// www.hukor. depkes.go.id/up_prod permenkes/PMK\%20No.\%20492\% 20ttg\%20Persyaratan $\% 20$ Kualitas \%20Air\%20Minum.pdf.

Khushboo, P., Lipsa, S., Priti, Y., Divya, P., Kaenat, S., Shivani, P. (2014). Alkaline Water: The Disease Fighting Water. World Journal of 
Pharmaceutical Research, 3(3), 3845-53.

Kilmet, F. (2013). Alkaline Water In The Natural Treatment Of Asthma And Allergies [Internet]. Water For Health. . Available from: http://www.water-for-

health.co.uk/wp/wp

content/uploads/2013/04/water-forhealth-23.jpeg.

Rosa, MCI, Kyung-Bok J and Kyu-Jae L. (2012). Clinical Effect and Mechanism of Alkaline Reduced Water. Journal of Food and Drug Analysis. 1(20), 394-97.

Siswantoro, Edy., Nasrul, Hadi Purwanto., Sutomo. (2018). Efektivitas Konsumsi Air Alkali Terhadap Penurunan Kadar Gula Darah Acak pada Penderita Diabetes Mellitus Tipe 2. Jurnal Keperawatan. 11(1), 10-21.

Shinya, H. (2009). The Miracle of Enzyme Selfhealing Program. Bandung: PT Mizan Pustaka;

Shirahata, S., Hamasaki, T., Teruya, K. (2012). Advanced Research on The Health Benefit of Reduced

Water. Trends in Food Science and Technology. Elsevier Ltd; 23(2):124-31.

Thomas, MF., Ahmed, M., Huasheng, L., Jay, T., Jeremy, H., Nader, DH. (2008). Pyruvate Dehydrogenase
Complex Activity Controls

Metabolic and Malignant

Phenotype in Cancer Cells. $J$ Biol Chem. 2008; 283(33):22700-08.

Timpano, A.J., S.H. Schoenholtz, C.E. Zipper, D.J. Soucek (2010). "Isolating effects of total dissolved solids on aquatic life in central Appalachian coalfield streams" Proceedings America Society of Mining and Reclamation 2010. [Online]. Hlm. 1284-1302. Tersedia di: http://www.asmr.us/Publications/ Conference\%20Proceedings/2010/ 1284-Timpano-VA.pdf [16 Okt 2015].

Yudo, S., dan Raharjo, P. N. (2005). Evaluasi Teknologi Air Minum Isi Ulang di DKI Jakarta. JAI, (1)3, 251-263.

Yustina, W., Nahwa, A., Galuh, H. 2016. Pengaruh Pemberian Air Alkali Terionisasi terhadap Kualitas Hidup Anak Asma. Jurnal Kedokteran Diponegoro. Vol. 5, No. 4, Online : Http://EjournalS1.Undip.Ac.Id/Index.Php/Medico Issn Online : 2540-8844.

Wan-Jun Z, Masaaki N, Takefumi M, Kiyotaka H, Hiroyuki T, Junichiro $\mathrm{K}$, et al. 2013. Amelioration Of Cardio-Renal Injury With Aging In Dahl Salt-Sensitive Rats By H2Enriched Electrolyzed Water. Medical Gas Research. 3(26):1-8. 